\title{
Inheritance of Resistance to Pear Psylla Nymphal Feeding in Pear (Pyrus communis L.) of European Origin
}

\author{
Richard L. Bell ${ }^{1,2}$ \\ U.S. Department of Agriculture, Agricultural Research Service, Appalachian \\ Fruit Research Station, 2217 Wiltshire Road, Kearneysville, WV 25430
}

Additional index words. pear, Cacopsylla pyricola, Hemiptera, antixenosis, insect resistance, germplasm resources

\begin{abstract}
Pear psylla are serious pests of pear throughout North America and Europe. Inhibition of nymphal feeding has been identified as a key component of resistance, being correlated with inhibition of oviposition, mortality, and delayed development. Breeding for resistance would be aided by knowledge of the inheritance and relative breeding values of resistant parents. Nine seedling populations derived from crosses among five resistant European $P$. communis cultivars ('Batjarka', 'Erabasma', 'Ilinjaca', 'Spina Carpi', and 'Zelinka'), a clone labeled 'Obican Vodenac', and two susceptible $P$. communis parents ('Bartlett' and 'Sunrise') were used in this study. The seedlings, 'Bartlett' as a susceptible control and NY10353 (a $P$. communis $\times P$. ussuriensis backcross hybrid) as a moderately resistant control, were assayed for short-term survival and nymphal feeding after an infestation period of 2 days. There were no significant differences among the progenies and controls in mean proportion of live nymphs after 2 days. The distributions of live and feeding nymphs indicated some dominance for susceptibility in some crosses. There were few significant differences among crosses in the proportion of actively feeding nymphs; however, the two crosses involving 'Erabasma' exhibited significantly less feeding, indicating that 'Erabasma' transmitted resistance to nymphal feeding to its progeny to a greater degree than the other four resistant parents.
\end{abstract}

Pear psyllids [Cacopsylla pyri (L.), C. pyricola (Förster), and C. pyrisuga (Förster)] are major arthropod pests of pear (Pyrus communis L.) throughout North America and Europe. Both adults and nymphs feed primarily in the vascular tissue of the leaves, petioles, and succulent shoots. Prolonged feeding in the phloem by nymphs affects the plant directly by inducing necrosis and premature defoliation. The nymphs excrete excess sugar as honeydew, which can cause russetting of young fruit. Sooty mold fungus grows on the honeydew, resulting in reduced photosynthesis and marked fruit. The insect is also the vector of the pear decline phytoplasma (Hibino et al., 1971). In North America, Cacopsylla pyricola has rapidly developed resistance to commonly used pesticides, including organophosphates and pyrethroids, and biological controls are not always sufficiently effective. Resistant cultivars would

\footnotetext{
Received for publication 26 Sept. 2012. Accepted for publication 11 Jan. 2013.

I acknowledge the technical contributions of Dan Bullock and Jonathan Daily.

Mention of trade names or commercial products in this publication is solely for the purpose of providing specific information and does not imply recommendation or endorsement by the U.S. Department of Agriculture.

USDA is an equal opportunity provider and employer.

${ }^{1}$ Research Horticulturist.

${ }^{2}$ To whom reprint requests should be addressed; e-mail richard.bell@ars.usda.gov.
}

as the measure of host resistance in this study.

Based on the distribution of counts of pear psylla nymphs in seedling trees derived from crosses of susceptible $P$. communis cultivars with $P$. ussuriensis 65 , a resistant open-pollinated selection, Harris and Lamb (1973) concluded that resistance was heritable and dominant. The only other published study of the inheritance of resistance to this pest confirmed the multigenic nature of genetic control and identified one quantitative trait locus (QTL) that explained 15\% of the phenotypic variability in a cross of 'Angelys' and NY 10355 and a few other minor QTLs (Bouvier et al., 2012). The variable analyzed was a subjective estimate of the number of first to third instar nymphs and presence of honeydew. The purpose of the present study was to assess the degree of inheritance of resistance to pear psylla nymphal feeding antixenosis as a key indicator of resistance and to determine the relative breeding values of a set of six resistant $P$. communis cultivars of European origin.

\section{Material and Methods}

Seedling populations and controls. Nine seedling populations derived from crosses among five resistant European $P$. communis cultivars ('Batjarka', 'Erabasma', 'Ilinjaca', 'Spina Carpi', and 'Zelinka'), a clone labeled 'Obican Vodenac', and two susceptible $P$. communis parents ('Bartlett' and 'Sunrise') (Table 1) were used in this study. Trees of 'Obican Vodenac' were originally determined to be resistant, but trees labeled with the same cultivar name used in the crosses were subsequently determined to be susceptible, probably as a result of mislabeling at some point in budwood distribution or propagation. 'Sunrise' is a new, high-quality, fireblight-resistant cultivar being used as a parent in the USDA pear breeding program (Bell and van der Zwet, 2011). The number of seedlings assayed varied from 14 to 35 . Each seedling had been grown in a greenhouse under standard horticultural practices in 6-inch pots with Metro-Mix 500 (ScottsSierra Horticultural Products Company, Marysville, $\mathrm{OH})$ potting soil containing a starter fertilizer and after 4 weeks fertilized weekly with Peter's Professional General Purpose 20-20-20 Fertilizer (Scotts-Sierra Horticultural Products Company, Marysville, $\mathrm{OH})$. Trees of a moderately resistant control, NY10353 (a $P$. communis $\times P$. ussuriensis backcross hybrid), and a susceptible control, 'Bartlett', were propagated on 'Bartlett' seedling rootstock and grown in an identical manner. No residual or systemic pesticides were used on these plants with only Safer's Insecticidal Soap (Safer Brand, Lititz, PA) used to control greenhouse pests. During the course of the study, powdery mildew was controlled by infrequent applications of fungicides, but no fungicides were used within 2 weeks of using the plants in assays.

Resistance assay. The top two youngest, fully expanded leaves of each plant were each 
Table 1. Progeny means for proportion live and feeding nymphs.

\begin{tabular}{lccc}
\hline Cross $^{\mathrm{z}}$ or control & No. of plants $^{\mathrm{y}}$ & Proportion feeding & Proportion live \\
\hline Bartlett & 31 & $0.78 \mathrm{a}^{\mathrm{x}}$ & $0.88 \mathrm{a}$ \\
Obican Vodenac $\times$ Sunrise & 26 & $0.76 \mathrm{a}$ & $0.83 \mathrm{a}$ \\
Spina Carpi $\times$ Bartlett & 28 & $0.73 \mathrm{a}$ & $0.83 \mathrm{a}$ \\
Obican Vodenac $\times$ Bartlett & 35 & $0.73 \mathrm{a}$ & $0.80 \mathrm{a}$ \\
Ilinjaca $\times$ Bartlett & 15 & $0.69 \mathrm{a}$ & $0.81 \mathrm{a}$ \\
Zelinka $\times$ Bartlett & 18 & $0.67 \mathrm{a}$ & $0.81 \mathrm{a}$ \\
Batjarka $\times$ Sunrise & 26 & $0.66 \mathrm{a}$ & $0.77 \mathrm{a}$ \\
Zelinka $\times$ Sunrise & 29 & $0.62 \mathrm{a}$ & $0.78 \mathrm{a}$ \\
Erabasma × Sunrise & 14 & $0.43 \mathrm{~b}$ & $0.71 \mathrm{a}$ \\
Erabasma $\times$ Bartlett & 17 & $0.42 \mathrm{~b}$ & $0.72 \mathrm{a}$ \\
NY10353 & 9 & $0.23 \mathrm{c}$ & $0.75 \mathrm{a}$ \\
\hline
\end{tabular}

${ }^{\mathrm{z}}$ Resistant parent is listed first, regardless of the direction of the cross.

y The plants for the 'Bartlett' and NY 10353 were clonally propagated, whereas each plant for the crosses was self-rooted individual seedlings.

${ }^{\mathrm{x}}$ Mean separation using Waller-Duncan k-ratio $t$ test $($ K-ratio $=100)$ option of SAS PROC GLM (SAS Institute, Inc., 2010). Means followed by different letters are significantly different at the $P=0.05$ level.

infested by transferring 10 second or third instar nymphs of pear psylla (Cacopsylla pyricola) from a young laboratory colony onto the abaxial side of the leaves with a single-hair brush. All but the top four leaves were removed, and a band of Tangle-Trap (The Tanglefoot Company, Grand Rapids, MI) was applied to the stem just basal to the fourth node to trap nymphs migrating off of the plant. After infestation, the plants were maintained in a growth chamber at $25 \pm 1{ }^{\circ} \mathrm{C}$ and a photoperiod of $16 \mathrm{~h} / 8 \mathrm{~h}$ (light/dark) provided by incandescent and high-intensity fluorescent bulbs. The experiment was conducted in daily sets of eight to 10 seedlings and one tree of the susceptible control, 'Bartlett'; in nine trials, trees of the resistant control, NY10353, was assayed. The number of dead, present and surviving, and the number of actively feeding nymphs were counted after $48 \mathrm{~h}$. Active feeding was indicated by the presence of excreted "honeydew" associated with the nymph. Missing nymphs as well as those that migrated off of the four test leaves and down the plant stem were presumed to be reacting to the antixenotic property of the host genotype. The number of feeding nymphs and the number live were divided by the original 20 nymphs to compute the corresponding proportions.

Statistical analysis. All analyses were performed using procedures of SAS 9.2 (SAS Institute, Inc., 2010). Descriptive statistics for each cross were generated using SAS PROC MEANS. Data for proportion alive and proportion feeding were analyzed to determine whether the residuals met the assumptions underlying the analysis. Residuals were generated using SAS PROC GLM using Type III sums of squares. Homogeneity of variances was tested by an examination of residual plots. Normality was tested using the Shaprio-Wilk test in SAS PROC UNIVARIATE and examination of box plots, normal probability plots, and histograms fitted with a normal distribution. Correlation of mean and residuals was examined using a plot of residual vs. predicted values and tested by SAS PROC CORR option SPEARMAN. The Shapiro-Wilk tests rejected the null hypothesis of a normal distribution for proportion live $(\mathrm{W}=0.95$,
$\operatorname{Pr}<\mathrm{W}=0.0001)$ and proportion feeding ( $\mathrm{W}=$ $0.97, \operatorname{Pr}<\mathrm{W}=0.0003$ ), and examination of box and normal probability plots revealed slight deviations from normality. Predicted means and variances were not correlated (proportion live: $r=-0.05, \operatorname{Pr}>r=$ 0.51 ; proportion feeding: $r=-0.09, \operatorname{Pr}>$ $r=0.25$ ). Transformation using the $\arcsin$ square root function slightly improved the results of the Shapiro-Wilk test and plots as well as the correlations between predicted and residual values. Therefore, the arcsin transformed data were used for further analysis.

Differences among progeny means were analyzed using SAS PROC GLM according to a completely randomized design. Mean separation for this procedure was performed using the Waller-Duncan k-ratio $t$ test (Kratio $=100)$. Although the crosses did not form a complete six $\times$ two factorial design, with three crosses with insufficient seedlings for analysis, the data were analyzed according to a factorial design to detect differences among the resistant parents and the susceptible parents and to test for interactions among parents. This analysis was performed using SAS PROC GLM with resistant and susceptible parents as fixed effects, Type 4 sums of squares, and the Waller-Duncan k-ratio test for mean separation of the resistant parents. The difference between the susceptible parents was determined by an F-test. In another analysis, the resistant and susceptible parents were treated as random effects under the assumption that they could be considered to be randomly chosen from the population of psylla-resistant east European cultivars and susceptible west European germplasm. Variance components were generated using SAS PROC VARCOMP with the REML estimation method.

Progeny means for proportion of feeding nymphs were regressed on the mean proportion of feeding for the resistant parent to estimate the narrow-sense heritability of nymphal feeding antixenosis (Falconer, 1989). SAS PROC REG (SAS Institute, Inc., 2010) was used for this analysis. The parental values had been determined in previous research (Bell, 1992, 2003; Bell and Stuart, 1990; Bell and van der Zwet, 1998; Bell, unpublished data). The narrow-sense heritability value is an estimate of the degree to which progeny means could be predicted based on the degree of feeding antixenosis exhibited by the "resistant" parent.

\section{Results and Discussion}

The distributions for proportion alive and proportion feeding were continuous for seedling values within all crosses with no evidence for segregation into discrete resistant and susceptible classes. The distributions of proportion live nymphs in five of the nine crosses were significantly skewed with higher proportions of live, suggesting some dominance for susceptibility. Only the W-statistics for 'Obican Vodenac' $\times$ 'Bartlett', 'Bartlett' $\times$ 'Ilinjaca', 'Erabasma' $\times$ 'Bartlett', and 'Sunrise' $\times$ 'Batjarka' for proportion alive were non-significant, indicating normality. The distributions of proportion feeding for six of the nine crosses were significantly skewed with higher proportions of feeding, indicating dominance for susceptibility (Falconer, 1989). Only the W-statistics for 'Erabasma' $\times$ 'Bartlett', 'Erabasma' $\times$ 'Sunrise', and 'Bartlett' $X$ 'Ilinjaca' were non-significant, indicating no serious deviation from a normal distribution. It is interesting that two of the three populations with normal distributions were the least susceptible populations. These results are in contrast to those of Harris and Lamb (1973), who found dominance of resistance in nymphal population counts in seedling populations in the orchard. It is possible that the inheritance of the other modes of resistance, ovipositional antixenosis and antibiosis, are controlled by dominant genetic factors. The differences may also be the result of genetic background because the population investigated by Harris and Lamb (1973) was derived from P. ussuriensis

The mean proportion of live nymphs after $2 \mathrm{~d}$ ranged from 0.71 for the 'Erabasma' $\times$ 'Sunrise' cross to 0.88 for the susceptible control 'Bartlett' (Table 1). There were no significant differences among crosses, indicating that antibiosis within the short period of $2 \mathrm{~d}$ was not significant. There were no significant differences in the proportion of dead nymphs (data not presented). There were few significant differences among crosses in the proportion of actively feeding nymphs. Mean proportion of nymphal feeding in one group of seven crosses ranged from 0.76 to 0.62 and was not significantly different from the susceptible control, 'Bartlett'. However, the two crosses involving 'Erabasma' exhibited significantly less psyllid feeding, 0.42 and 0.43 , indicating that 'Erabasma' transmitted resistance to its progeny to a greater degree than the other parents.

The factorial analysis confirmed that 'Erabasma' transmitted resistance to its progeny, whereas the susceptible parents were virtually identical in their effect on nymphal feeding (Tables 2 and 3). The effect of a resistant parent was significant for proportion of feeding, whereas the effects of a susceptible parent and the interaction of resistant and susceptible 
Table 2. Mean proportion of pear psylla nymphal feeding and marginal parental means.

\begin{tabular}{|c|c|c|c|c|c|}
\hline \multirow[b]{3}{*}{ Resistant parent } & \multicolumn{4}{|c|}{ Susceptible parent } & \multirow{3}{*}{$\begin{array}{c}\text { Marginal parental } \\
\text { mean }\end{array}$} \\
\hline & \multicolumn{2}{|c|}{ Bartlett } & \multicolumn{2}{|c|}{ Sunrise } & \\
\hline & No. & Mean & No. & Mean & \\
\hline Obican Vodenac & 26 & 0.73 & 25 & 0.76 & $0.745 \mathrm{a}^{\mathrm{z}}$ \\
\hline Spina Carpi & 27 & 0.73 & - & - & $0.730 \mathrm{a}$ \\
\hline Ilinjaca & 15 & 0.69 & - & - & $0.690 \mathrm{a}$ \\
\hline Batjarka & - & - & 25 & 0.66 & $0.660 \mathrm{a}$ \\
\hline Zelinka & 12 & 0.67 & 24 & 0.62 & $0.645 \mathrm{a}$ \\
\hline Erabasma & 17 & 0.42 & 14 & 0.43 & $0.425 \mathrm{~b}$ \\
\hline Marginal parental mean & 71 & $0.65 \mathrm{a}$ & & 88 & $0.62 \mathrm{a}$ \\
\hline
\end{tabular}

Table 3. Statistical analysis ${ }^{z}$ of resistance according to the factorial crossing design.

\begin{tabular}{|c|c|c|c|c|c|c|c|}
\hline \multirow[b]{2}{*}{ Source } & \multirow[b]{2}{*}{ df } & \multicolumn{3}{|c|}{ Proportion feeding } & \multicolumn{3}{|c|}{ Proportion live } \\
\hline & & MS & $\operatorname{Pr}>F$ & Variance $^{\mathrm{y}}$ & MS & $\operatorname{Pr}>F$ & Variance $^{z}$ \\
\hline Resistant parent (R) & 5 & 0.589 & 0.0002 & 0.0298 & 0.076 & 0.5704 & 0.0027 \\
\hline Susceptible parent (S) & 1 & 0.008 & 0.7207 & 0.0000 & 0.007 & 0.6987 & 0.0000 \\
\hline $\mathrm{R} \times \mathrm{S}$ Interaction & 2 & 0.031 & 0.6180 & 0.0000 & 0.022 & 0.6332 & 0.0000 \\
\hline Residual $^{\mathrm{x}}$ & 183 & 0.064 & 一 & 0.0672 & 0.050 & 一 & 0.0504 \\
\hline
\end{tabular}

${ }^{\mathrm{z}}$ Analysis computed by SAS PROC GLM (SAS Institute, Inc., 2010).

y Variance component estimated by SAS PROC VARCOMP with MIVQUE0 method (SAS Institute, Inc., 2010).

${ }^{\mathrm{x}}$ Residual is that variance is the result of differences among seedlings.

parents were not significant. Because of a lack of significant differences among crosses in proportion of live nymphs, a similar analysis of this variable was not performed.

Lack of transmission of resistance could be the result of genetic factors, that is, inherent low narrow-sense heritability resulting from multiple genetic factors controlling the trait. Pasqualini et al. (2006) did not find high levels of resistance in many selections from some interspecific crosses involving NY 10353 and NY 10355 and observed that transmission of resistance depended on the parental combination. They concluded that resistance is polygenic. Feeding may be enhanced by excessive vigor of the plants, but this did not appear to be true with the plants used in this study. Growth was uniform among the test plants. In addition, the proportion of feeding on the resistant control, NY10353, was not excessive and was consistent with values observed in previous studies, 0.17 (Bell and van der Zwet, 1998) and 0.27 (Bell, 2003).

The regression of progeny means for feeding onto the mean feeding of the resistant parent was not significant $(\mathrm{b}=0.26$; $\mathrm{SE}_{\mathrm{b}}=0.13 ; \operatorname{Pr}>\mathrm{F}=0.10 ; h^{2}=0.13$ ). Therefore, for this small set of crosses, the narrow-sense heritability could not be accurately determined. Analysis of a larger set of crosses may allow determination of heritability of nymphal feeding antixenosis. The present study was based on a qualitative measure of resistance, presence or absence of nymphal ingestion, and excretion. In addition, quantitative methods of measuring the amount of honeydew produced may be useful in characterizing resistance (Smith et al., 1994).
On the basis of the results, the preferential use of 'Erabasma' can be recommended for the development of resistant cultivars. The fruit quality of 'Erabasma' is similar to that of 'Batjarka', 'Ilinjaca', Spina Carpi', and 'Zelinka' (Bell and van der Zwet, 1998) in that the flesh texture is coarse and crisp. Although susceptible to fireblight, the east European psylla-resistant cultivars are generally resistant to Fabraea leaf and fruit spot. Although grown as local cultivars, their fruit quality does not meet the standards for commercial pears typical of west European pear cultivars. The relative lack of transmission to their progeny of high-level resistance to nymphal feeding by the other resistant cultivars indicates that the inheritance of the other modes of resistance, ovipositional antixenosis and antibiosis (mortality and delayed development), should also be investigated to determine relative breeding values based on all modes of host resistance to pear psylla of prospective parents (Smith et al., 1994).

\section{Literature Cited}

Bell, R.L. 1991. Ovipositional antixenosis-based host resistance to the pear psylla in Pyrus germplasm of east European origin. HortScience 26:710.

Bell, R.L. 1992. Additional east European Pyrus germplasm with resistance to pear psylla nymphal feeding. HortScience 27:412-413.

Bell, R.L. 2003. Resistance to pear psylla nymphal feeding of germplasm from central Europe. Acta Hort. 622:343-345.

Bell, R.L. and L.C. Stuart. 1990. Resistance in eastern European Pyrus germplasm to pear psylla nymphal feeding. HortScience 25:789-791.

Bell, R.L. and T. van der Zwet. 1998. Breeding for host resistance to pear psylla: Evaluation of parental germplasm. Acta Hort. 484:471475 .

Bell, R.L. and T. van der Zwet. 2011. 'Sunrise' pear. HortScience 46:118-120.

Berrada, S., T.X. Nguyen, J. Lemoine, J. Vanpoucke, and D. Fournier. 1995. Thirteen pear species and cultivars evaluated for resistance to Cacopsylla pyri (Homoptera: Psyllidae). Environ. Entomol. 24:1604-1607.

Bouvier, L., M. Bourcy, M. Boulay, M. Tellier, P. Guérif, C. Denancé, C.-E. Durel, and Y. Lespinasse. 2012. European pear cultivar resistance to bio-pests: Scab (Venturia pirina) and psylla (Cacopsylla pyri). Acta Hort. 909:459470.

Briolini, G., A.L. Cappeli, L. Rivalta, and P. Rosati. 1988. Observations on Pyrus communis resistance to Psylla pyri. Acta Hort. 224: 211-221.

Butt, B.A., L.C. Stuart, and R.L. Bell. 1988. Feeding behavior of pear psylla (Homoptera: Psyllidae) nymphs on susceptible and resistant Pyrus germplasm. J. Econ. Entomol. 81:1394 1397.

Butt, B.A., L.C. Stuart, and R.L. Bell. 1989 Feeding, longevity, and development of pear psylla (Homoptera: Psyllidae) nymphs on resistant and susceptible pear genotypes. J. Econ. Entomol. 82:458-461.

Falconer, F.D.S. 1989. Introduction to quantitative genetics. Longman, Burnt Mill, Harlow, UK.

Harris, M.K. 1973. Host resistance to the pear psylla in a $P$. communis $\times P$. ussuriensis hybrid. Environ. Entomol. 2:883-887.

Harris, M.K. and R.C. Lamb. 1973. Resistance to the pear psylla in pears with Pyrus ussuriensis lineage. J. Amer. Soc. Hort. Sci. 98:378-381.

Hibino, H., G.H. Kaloostian, and H. Schneider 1971. Mycoplasma-like bodies in the pear psylla vector of pear decline. Virology 43 : 34-40.

Pasqualini, E., S. Civolani, S. Musacchi, V. Ancarani, and L. Dondini. 2006. Cacopyslla pyri behavior on new pear selections for host resistance programs. Bull. Insectology 59: 27-37.

Puterka, G. 1997. Intraspecific variation in pear psylla (Homoptera: Psyllidae) nymphal survival and development on resistant and susceptible pear. Environ. Entomol. 26:552-558.

Puterka, G.L., R.L. Bell, and S.K. Jones. 1993 Ovipositional preference of pear psylla (Homoptera: Psyllidae) for resistant and susceptible pear. J. Econ. Entomol. 86:1297-1302.

Quamme, H.A. 1984. Observations of psylla resistance among several pear cultivars and species. Fruit Var. J. 38:34-36.

Quarta, R. and D. Ruggioni. 1985. Survey on the variety susceptibility to pear psylla. Acta Hort. 159:77-86.

Robert, P., J. Chausset, and M. Le Lézec. 1999. Larval development of Cacopsylla pyri (L.) [Homoptera: Psyllidae] on two resistant Pyrus genotypes. IOBC WPRS Bull. 22:89-91.

SAS Institute, Inc. 2010. SAS for Windows, Version 9.22, SAS Institute, Inc., Cary, NC.

Smith, C.M., Z.R. Khan, and M.D. Pathak. 1994. Techniques for evaluating insect resistance in crop plants. CRC Press, Boca Raton, FL.

Westigard, P.H., M.N. Westwood, and P.B. Lombard. 1970. Host preference and resistance of Pyrus species to the pear psylla, Psylla pyricola Föerster. J. Amer. Soc. Hort. Sci. 95:34-36. 